\title{
Critical evaluation of the off-label indication and of the risks associated to the use of multi-dose vials on the treatment of age-related macular degeneration
}

\author{
Bruna Renata Dutra Barbosa ${ }^{1}$, Sávio Fujita Barbosa ${ }^{2, *}$, Guilherme Diniz Tavares ${ }^{2}$, \\ Nádia Araci Bou Chacra², Terezinha de Jesus Andreoli Pinto ${ }^{2}$
}

\author{
${ }^{1}$ Faculty of Pharmaceutical Science, Faculty Oswaldo Cruz, São Paulo, SP, Brazil, ${ }^{2}$ Departament of Pharmacy, Faculty of \\ Pharmaceutical Sciences, University of São Paulo, São Paulo, SP, Brazil
}

\begin{abstract}
Age-related macular degeneration (AMD) is an ocular inflammatory diseases treated mainly by means of a bevacizumab (Avastin ${ }^{\circledR}$ ) or ranibizumab (Lucentis ${ }^{\circledR}$ ) intravitreal injection. Among these drugs, only ranibizumab has a specific therapeutic indication for AMD. Considering that, the off-label use on ophthalmic therapy seems to become a rule when it should be an exception. Furthermore, bevacizumab presentation consists of multi-dose vials although it does not contain preservatives in its formula. The current literature review aimed at assessing the risks for the patient related to the use of off-label indication and multi-dose vials on AMD treatment. Considering this, the proposal related to the Brazilian Public Consultation no.10, dated September 12, 2012, which proposes the Clinical Protocol and Therapeutic Guidelines for AMD treatment, was evaluated. This systematic review allowed to conclude that the bevacizumab off-label indication results in increased risks for the patient when compared to the product with specific therapeutic indication for AMD treatment (ranibizumab), especially referring to the significant raise in the adverse events. The risks for the patient related to the multi-dose vial use, referring to the microbiological stability and dose precision, were also made clear.
\end{abstract}

Uniterms: Age-related macular degeneration/treatment. Ranibizumab/intravitreal injection. Bevacizumab/ intravitreal injection. Ophthalmic therapy/off-label use. Off-label indication/patients risks. Multi-dose vials/patients risks.

A degeneração macular relacionada à idade (DMRI) é uma doença ocular inflamatória tratada principalmente por injeção intravítrea de bevacizumabe $\left(\right.$ Avastin $^{\circledR}$ ) ou de ranibizumabe (Lucentis ${ }^{\mathbb{R}}$ ). Entre os medicamentos citados, apenas o ranibizumabe tem indicação terapêutica específica para uso oftálmico. Considerando essa realidade, o uso off-label na terapia oftálmica parece constituir regra quando deveria ser exceção. Ademais, a apresentação do bevacizumabe consiste em frascos de múltipla-dose, embora esse medicamento não contenha conservante em sua fórmula. A presente revisão da literatura avaliou os riscos ao paciente relativos ao uso indicado off-label e de frascos de múltipla-dose no tratamento de DMRI. Nesse sentido, avaliou-se a proposta relativa à Consulta Pública Brasileira $n^{\circ} 10$, de 12 de setembro de 2012, que propõe o Protocolo Clínico e Diretrizes Terapêuticas para o tratamento de DMRI. O levantamento sistemático de trabalhos científicos e de informações relevantes de banco de dados eletrônicos permitiu concluir que a indicação off-label do bevacizumabe acarreta riscos maiores ao paciente, quando comparado ao produto com indicação terapêutica específica para o tratamento de DMRI (ranibizumabe), especialmente quanto ao aumento significativo de eventos adversos. Evidenciaramse, também, os riscos ao paciente relativos ao uso de frascos de múltipla-dose, quanto à estabilidade microbiológica e à precisão da dose.

Unitermos: Degeneração macular/tratamento. Ranibizumabe/injeção intravítrea. Bevacizumabe/injeção intravítrea. Terapia oftálmica/uso off-label. Indicação off-label/riscos ao paciente. Frascos de multi-dose/ riscos ao paciente.

\footnotetext{
*Correspondence: S. F. Barbosa. Departamento de Farmácia, Faculdade de Ciências Farmacêuticas, Universidade de São Paulo. Av. Prof. Lineu Prestes, 580, 05508-000 - São Paulo - SP, Brasil. E-mail: savio.barbosa@usp.br
} 


\section{INTRODUCTION}

The recombinant monoclonal antibodies (mAb) used in ophthalmic therapy consist of immunoglobulin produced from B cell clones which recognize specific antigens. Problems related to the rejection of said antibodies by the organism were circumvented by the adoption of humanized or completely human chimeric monoclonal antibodies. Chimeric monoclonal antibodies consist of human origin amino acid sequences, with murine origin sequences in the regions that bind to the antigenic determinants. A significant part of the amino acid sequences has a human origin in humanized antibodies, with a portion of less than $5 \%$ corresponding to murine origin. Human antibodies have $100 \%$ human origin sequences. Murine antibodies, or mouse antibodies, are identified by the immune system as foreign agents, inducing the organism to produce HAMA (human antimouse antibody). Thus, the organism quickly eliminates those antibodies and immune complexes, thus causing kidney injuries. Therefore, the therapeutic efficacy and the drug safety should be assessed by close clinical tests (Santos et al., 2006).

The main therapeutic use of monoclonal antibodies in ophthalmology refers to the treatment of inflammatory eye diseases, especially in cases of severe and refractory uveitis (Infliximab, Remicade ${ }^{\circledR}$, Janssen-Cilag; adalimumab, Humira $^{\circledR}$, Abbott), diabetic retinopathy (DR) and agerelated macular degeneration (AMD) (bevacizumab, Avastin $^{\circledR}$, Genentech; ranibizumab, Lucentis ${ }^{\circledR}$, Novartis) (Gragoudas et al., 2004; Santos et al., 2006; Rosenfeld et al., 2005, 2006; Rich et al., 2006). However, the authorized therapeutic indication for both drugs (infliximab and adalimumab) only includes treatments for rheumatoid arthritis, psoriatic arthritis, ankylosing spondylitis, Crohn's disease, psoriasis, and polyarticular juvenile idiopathic arthritis (Maini et al., 1999; Weinblat et al., 2003). Adalimumab shows a significant advantage when compared to infliximab (chimeric antibody) due to the totally humanized origin of this antibody (Wiens et al., 2010). For bevacizumab, the authorized therapeutic indication regards the treatment of neoplasms, such as metastatic colorectal cancer, lung cancer, breast cancer, metastatic renal cell cancer, among others (Ellis, 2006; Sandler et al., 2006; Santos et al., 2006; Miller et al., 2007; Roche, 2011). Thus, the off-label use of monoclonal antibodies in ophthalmic therapy seems to be a rule. Among these drugs, the only exception is ranibizumab, which shows specific therapeutic indication for AMD treatment.

The rationale provided by ophthalmologists for the non-authorized use of monoclonal antibodies in the treatment of severe and refractory uveitis has been based on its limited clinical success and on the partial failure of steroids and immunosuppressive drugs in eye inflammation control, as well as the increased rate of adverse events caused by steroid agents (Regatieri et al., 2010).

For neovascular diseases, the vascular endothelial growth factor (VEGF) actively participates in the formation of new vessels in several neovascular conditions, including diabetic retinopathy (DR) and AMD. The abnormal growth of blood vessels around the retina may cause sight loss (Regatieri et al., 2010). As an intravitreal injection, the anti-VEGF monoclonal antibody [bevacizumab (Avastin ${ }^{\circledR}$, Genentech)] and the VEGF fragment [ranibizumab (Lucentis ${ }^{\circledR}$, Novartis)] showed significant regression of choroidal and retinal neovascularization in experimental studies (Campochiaro, 2004). The apparent similarity in the therapeutic efficacy of these antibodies has justified the off-label use of bevacizumab by ophthalmologists.

This work aimed at reviewing the literature related to the off-label indication and the risks associated with the use of multi-dose vials in age-related macular degeneration treatment. For this purpose, a systematic survey of scientific works and of electronic database relevant information up to November 2012 was carried out.

\section{Off-label indications and drug promotional practices}

In Brazil, the registration of new drugs is granted after the confirmation of their quality, safety, and efficacy, and the last two characteristics should be supported by clinical trials. However, other indications, different from those for which the drug was granted the registration, may be proposed, at the prescribing physician's discretion and risk: this is off-label drug use. A typical example of a non-approved indication is the case of treatment in rare diseases. In these cases, it is not possible to perform a clinical trial to propose an indication; therefore, off-label drug use may be tolerated during an indefinite period of time (ANVISA, 2005).

The term "different situation" refers to nonapproved indications for which, after the assessment period, the industry proposes a registration change, such as, for example, requesting the extension of drug use for another age group or use for a different phase of the same disease for which the indication was approved, or even an extension of its indication for another disease. The latter can be exemplified with the case of bevacizumab. This drug, which was at first approved for treatment of metastatic colorectal cancer in 2004 , had its registration changed in 2006 and in 2008 . These changes regard the 
extension of therapeutic indications for lung and breast cancer treatment, approved by ANVISA.

On the other hand, the indication of a certain drug may be restricted when compared to the originally approved one. In this case, pharmacovigilance determines the damage caused by these marketed products, identifying the risk and interfering in a timely manner in the drug registration (ANVISA, 2012).

For the approval of a new therapeutic indication, the submission of the periodic safety reports and the risk minimization plan is mandatory, according to IN No. 14, which approved the Pharmacovigilance Guides for the performance of RDC No. 4, dated 2009. This safety assurance may be circumvented in case of off-label indication use, causing risks for patients.

The off-label indication may help fixing the gap between the time in which the research shows efficacy of a certain drug and formal approval by the regulatory agency. However, there's a thin line between the supply of information related to the off-label use of a product and its promotion for said usage. This practice may bring beneficial results, indicating new ways for scientific research on the standardization of indications and dosages. On the other hand, in addition to lack of therapeutic effect, it can also result in adverse reactions (Di Paolo et al., 2006; Naubert et al., 2004).

The more an off-label indication use is spread, the higher the possibility of the industry using this way to circumvent the applicable regulation - which has the objective of ensuring drug efficacy and safety. In the United States, one out of five prescriptions regards treatment for an illness for which the drug was not approved (Radley et al., 2006). This study revealed that most off-label uses happen without scientific support. It is estimated that $23 \%$ to $60 \%$ of these medications are responsible for adverse reactions in children (Naubert et al., 2004; Patel et al., 2007).

Recent cases justify the results related to the increased incidence of prescriptions without scientific support. In 2012, several frauds involving big and wellknown pharmaceutical industries were discovered. Among them, Abbott and GlaxoSmithKline (GSK) stand out. According to a report from the FDA (Food and Drug Administration) Office of Criminal Investigations, Abbott agreed to pay US\$ 1.6 billion in compensation for an advertisement considered to be deceiving in the United States. The company instructed its marketing departments on the creation of campaigns for the drug Depakote ${ }^{\circledR}$ for uses that had not been approved by the FDA. According to a report from the United States Department of Justice, Abbott created a specific department for marketing the drug in hospitals. Depakote ${ }^{\circledR}$ is indicated in cases of bipolar disorder and epilepsy; however, it was being sold for the treatment of dementia and autism (off-label indication). Legal documents also revealed that Abbott marketed the drug for the treatment of schizophrenia, although clinical tests failed to prove that it had greater efficacy when compared to antipsychotic drugs traditionally used in the treatment of this disease.

In an article published on The New York Times, another huge pharmaceutical industry, GlaxoSmithKline (GSK), stated that it will pay the amount of US\$ 3 billion in the USA in order to close a case of illegal drug advertisement and adoption of deceiving prices. This decision may put an end to what is considered to be the biggest Public Health fraud in the history of the country by United States government employees. The breaches indicated by the United States Department of Justice include: advertisements for the antidepressant Paxil ${ }^{\circledR}$ targeted patients under 18 years old, as the medication had the approval for adult use only; Wellbutrin ${ }^{\circledR}$, another antidepressant used to treat smoking, was marketed for uses not approved by the FDA, such as weight loss and treatment of sexual dysfunctions; in addition to claims that the company did not offer the government its best prices on the Medicare drug purchase program (The United States public health system). The drug promotion also involved the distribution of potentially deceiving articles published in medical magazines.

In April 2012, the United States pharmaceutical industry Merck, Sharp \& Dohme was convicted by the Boston District Court to pay a fine at the amount of approximately 322 million dollars due to Vioxx promotion. As per the legal decision, once approved, the drug cannot be marketed or promoted for so-called off-label use - any non-specified and non-approved use. In May 1999, the FDA approved the use of Vioxx for three indications, but did not approve its use for rheumatoid arthritis until April 2002. In the meantime, Merck promoted Vioxx for rheumatoid arthritis for almost three years. This promotion resulted in a warning letter from the FDA, issued in September 2001. In 2004, the product was withdrawn from market for causing risk of severe cardiovascular events in patients.

In light of the above, off-label drug use requires rigorous inspection by the regulatory agencies. Therefore, the proposal of replacing a drug indicated for AMD (neovascular form) treatment with another one with offlabel use, as provided for in ANVISA Public Consultation No. 10, dated September 12, 2012, may be considered to be at least a precedent for future cases and an incentive for the promotional practice of drug use for a non- 
approved indication. This issue presents itself with greater importance after a statement regarding the illegality and unconstitutionality of RDC No. 96/08, which regulates advertisement, publicity, information, and other practices aimed at divulgation or commercial promotion of drugs. Said position, which was restated on October 22, 2009, by the Supreme Federal Court, weakened the national regulatory framework created over a decade by ANVISA and enabled a wider exposure of the medical class to the promotion of off-label drug use.

\section{Bevacizumab off-label indication: efficacy and safety critical evaluation}

Regarding off-label indications, studies in animals have shown that bevacizumab has a longer half-life when compared to ranibizumab, which, on the other hand, has the following advantages: affinity 140 times higher than bevacizumab to its antigenic determinant; greater efficacy when diluted; lower immunogenicity.

In 2011 and 2012, two important comparative studies between bevacizumab and ranibizumab were published. These studies were conducted in 2011 by the CATT (Comparison of Age-Related Macular Degeneration Treatments Trial - United States) and IVAN (Inhibition of VEGF in Age-related Choroidal Revascularization United Kingdom) studies.

Regarding the test protocol for the study performed by CATT, the patients treated with bevacizumab did not receive the fractioned drug, as in clinical practice (offlabel use). A 2-mL aliquot from an ampoule was used to prepare a single syringe, while the remaining content of said ampoule was discarded (Martin et al., 2012).

Regarding the protocol related to the assay performed by the IVAN study, the procedures about the fractioning used are not described. Thus, the study does not allow for efficacy and safety comparison between fractioned bevacizumab, as used in clinical practice, and ranibizumab in single-dose vials (Chakravarthy et al., 2012).

An additional issue regards the lack of studies to establish the indicated dose of bevacizumab for AMD treatment. In the United States, the most common dose of this drug is $1.25 \mathrm{mg} / 0.05 \mathrm{~mL}$, whereas in other countries, the $2.50 \mathrm{mg} / 0.05 \mathrm{~mL}$ dose is frequently used. This recommendation was supported by the fact that the molar concentration after the intravitreal injection, using bevacizumab $1.50 \mathrm{mg}$, is similar to the one reached with a $0.5 \mathrm{mg}$ ranibizumab dose, as per a verbal communication from Professor Rosenfeld, University of Miami, Florida.

In the same way, no pharmacokinetics, pharmacodynamics, toxicology, and long-term safety (chronic use medication) studies were performed, as well as safety studies in elderly populations. Of note, these studies are essential for the approval and marketing of a new drug by the regulatory agencies by ANVISA, including in Brazil.

Regarding bevacizumab safety, the package insert reports VEGF systemic concentration reduction after intravitreal anti-VEGF therapy. Non-ocular systemic adverse events, including hemorrhages and arterial thrombotic events, have been reported after intravitreal injection; thus, there is a theoretical risk that these conditions may be related to systemic VEGF inhibition.

Furthermore, the IVAN study showed that the systemic VEGF median concentrations were significantly lower with bevacizumab use in comparison with ranibizumab (Chakravarthy et al., 2012). This result may impair neuronal cell survival, endothelial cell survival and proliferation, bone growth, and regeneration of fractures.

In the CATT study, the authors reported a higher quantity of serious systemic adverse events in patients treated with bevacizumab $(24.4 \%)$. These results refer to the second year only, against $18 \%$ for ranibizumab. Considering the trend adjustments for the demographic characteristics and the concurrent diseases from the beginning of the groups, the risk of all severe systemic adverse events for bevacizumab is $30 \%$ higher when compared to the adverse events for ranibizumab (Martin et al., 2012).

Furthermore, a higher trend of venous thromboembolic events has been seen in treatments using Avastin ${ }^{\circledR}(1.7 \%)$ when compared to treatments using Lucentis $^{\circledR}(0.5 \%)$. Gastrointestinal events have been seen with a higher frequency (hemorrhage, hernia, nausea, and vomiting) in patients treated with bevacizumab, $4.8 \%$ and $1.8 \%$, respectively, for bevacizumab and ranibizumab $(p$-value $=0.005)($ Martin et al., 2012)

The Data and Safety Monitoring Committee of the IVAN clinical trial requested that the investigators perform new analyses of the safety results, joining the available data from the IVAN and CATT studies. This analysis was requested due to the statistic difference seen in the frequency of serious adverse events. The analysis confirmed a higher frequency of these events in patients treated with bevacizumab. The committee concluded that this result could not be seen as random.

Regarding long-term studies, ranibizumab has shown an adverse event rate similar to that of pivotal studies. This study enrolled patients under medication for a period of up to 7 years [Marina (Minimally Classic) Occult Trial of the Anti-VEGF Antibody Ranibizumab in the treatment of Neovascular AMD) and ANCHOR 
(Anti-VEGF Antibody for the Treatment of Predominantly Classic CNV in AMD)] (Brown et al., 2006; Rosenfeld et al., 2006).

The adverse events due to off-label use reported in the European package insert of the drug bevacizumab are: infectious endophthalmitis, intraocular inflammation (sterile uveitis, endophthalmitis, and vitritis), retinal detachment, retinal pigment epithelium tears, increased intraocular pressure, intraocular hemorrhage, such as vitreous hemorrhage or retinal hemorrhage, and conjunctival hemorrhage. On the other hand, the adverse events that are considered frequent for ranibizumab (affecting more than 1 out of 10 patients) and highlighted in its package insert are: eye inflammation, eye bleeding, visual disturbance, eye pain, small particles or stains in sight (vitreous floaters), blood stain in the eye, eye irritation, sensation of speck in the eye, increased tear production, eyelid margin inflammation or infection, dry eyes, eye redness or itchy eye, and increased intraocular pressure.

Considering that drug use shows a higher frequency among the elderly population, safety studies on this population have a major importance. Ranibizumab adverse events are known and did not show any increase in frequency in this age group, as reported on its package insert.

However, on the bevacizumab package insert, several warnings related to the type and frequency of serious adverse events are reported. Randomized clinical assays of bevacizumab (in the oncologic indication) with patients in the 65 years old or older age group showed increased risk of developing arterial thromboembolic events, including cerebrovascular accidents (CVA), transient ischemic attacks (TIA), and myocardial infarctions (MI). These diseases are exactly the ones which show a higher incidence in the elderly population. The additional adverse events reported on the package insert and associated with this drug are: grade 3 and 4 leukopenia, thrombocytopenia, neutropenia, diarrhea, headache, nausea, and fatigue.

An additional issue related to bevacizumab safety regards its use in patients with renal failure $(68 \%$ of patients with AMD have renal failure), diabetes, specially on the effect of wound healing, and hypertension. For the latter condition, a 34\% increase was seen in its incidence after treatment with bevacizumab (Ranpura et al., 2012; Scartozzi et al., 2009). Lastly, the association of this drug to bisphosphonates (a drug distributed by SUS [Unified Health System]) for the treatment of osteoporosis may cause an increase in the incidence of mandible osteonechrosis.

\section{Risks associated with fractioning multi-dose vials of parenteral drugs}

Drugs with parenteral administration differ from other dosage forms, as they show unique requirements, due to the fact that they are injected directly into the body tissue through the main human body protection system, the skin (and mucous membranes). For this reason, these drugs should have the following characteristics: exceptional purity; lack of physical and chemical contaminants; and sterility (Avis, Levchuk, 2000).

With regard to parenteral drugs, it is essential that their primary package maintain its sterility until the time of use. In addition to this basic requirement, the packages used in the storage of sterile products should be compatible with the sterilization method, be durable, provide permanent sealing, avoid the entrance of contaminants and allow the withdrawal of its content without recontamination (Garfinkle, Henley, 2000).

Among packages for injectable drugs, multi-dose vials are the most popular, as they are more convenient and cost-effective (Motamedifar, Askarian, 2006). Nowadays, the term "multi-dose vial" is used in a confusing way by healthcare professionals. In daily practice, the term means any kind of vial that has been used more than once and that was stored for potential re-use. (Mattner,Gastmeier, 2004).

According to the Brazilian Pharmacopeia (2010), packages for multi-dose vials are airtight containers that allow the withdrawal of successive portions of its content, without modifying the strength, purity, and sterility of the remaining portion. The American Pharmacopeia also declares that multi-dose vials should contain preservative agents, except in cases in which the product's components themselves have adequate antimicrobial properties, and that the volume should not exceed $30 \mathrm{~mL}$. These specifications are required by the official compendia because, even with asepsis precautions (including sterile needles and syringes for dose withdrawal and closure surface disinfection), there is a significant risk of microbiological contamination in the package content.

Despite their advantages, multi-dose vials show high risks of microbiological contamination due to their repeated use. Related studies indicate that potentially pathogenic microorganisms may survive and, sometimes, proliferate in multi-dose vials, thus creating a potential risk for parenteral inoculation of pathogenic organisms (Nakashima et al.,1987; Dade et al., 2000).

The multi-dose vial contamination rate is estimated to be up to $27 \%$; the consequences of said contaminations may be severe and may lead to nosocomial outbreaks of fungal, viral, and bacterial infections (Henry et al., 2001; 
Kirschke et al., 2003; Mattner et al., 2004; Melnyk et al., 1993; Moro et al., 1990).

Between 1985 and 2002, multi-dose vial contaminations and infections by HIV, by the hepatitis $\mathrm{B}$ and $\mathrm{C}$ viruses, by Plasmodium falciparum (Malaria), by Enterobacter cloacae, by Pseudomonas aeruginosa, among other pathogens, were reported in patients that used drugs and saline solutions from those vials (Mattner, Gastmeier, 2004).

Prevalence studies developed in Germany with the objective of assessing the multi-dose vial microbiological contamination showed that, out of 227 available vials in a certain hospital (1,300 beds), 2 ( $0.9 \%)$ were contaminated by Staphylococcus epidermidis, 114 (50\%) were showing the opening date, 44 units (19\%) were stored under refrigeration, and $109(48 \%)$ of the drugs did not have preservatives in their formulation (Mattner, Gastmeier, 2004).

A similar research conducted in Hospital Namzi, in Iran, showed that, out of 637 assessed vials, 36 (5.6\%) presented microbiological contamination, without any difference in the contamination between the different wards of the hospital or different types of medication. In this research, the most commonly identified microorganisms were part of the commensal microbiota, whereas Gram-positive bacteria (88.9\%) were significantly more identified than Gram-negative ones (11.1\%), with a higher frequency for Staphylococcus epidermidis (44.4\%) and a lower frequency for Actinomyces viscosus (2.8\%).

Aware of the risks inherent to the unsafe medical practice of dose fractioning, the American Pharmacopeia, in its $28^{\text {th }}$ Edition, dated 2005, included chapter $<797>$ Pharmaceutical Compounding-Sterile Preparations, which describes the basic requirements applied to health institutions, drugstores, medical facilities, and other facilities where pharmaceutical compounds and sterile preparations are manipulated, stored, and supplied. In this chapter, information on clean area specifications, environmental microbiological control, quality assurance programs, standard operational procedures, validations, periodical trainings, and aseptic manipulation assessment are required, in order to avoid unsafe practices, which cause a higher risk of disease for the patients.

\section{Endophthalmitis and other risks related to bevacizumab multi-dose vial fractioning}

Currently, injectable intravitreal administration of drugs has become widely used for the treatment of several retinal eye disorders. Intravitreal therapies are generally applied in medical clinics and in surgical environments, turning the risk of endophthalmitis into a major concern (Artunay et al., 2009).

Endophthalmitis is a serious intraocular inflammation, resulting from an eye cavity infection. Exogenous endophthalmitis occurs when infectious organisms develop in the eye due to their direct inoculation, by intraocular surgeries, traumas, or intravitreal injections (Lemley et al., 2007).

Several relevant issues about bevacizumab fractioning should be considered. Among them, the medication stability and sterility during the manipulation in the fractioning process should be assured, in order to avoid serious adverse events widely described in medical literature.

In recent investigations of infectious endophthalmitis outbreaks after intravitreal administration of the drug bevacizumab, a positive bacteria culture, including Streptococcus mitis/oralisit has been identified on the majority of patients and on the syringes used. The most probable cause appointed by researchers was contamination during syringe preparation, even with the use of aseptic techniques (Artunay et al., 2009; Goldberg et al., 2012).

In addition to the problems related to microbiological contamination, other researches that assessed the risks related to bevacizumab fractioning observed significant differences on the amount of bevacizumab between syringes resulting from fractioning, with an increase of up to 10 times in particulate material when compared to the original ampoule, and with contamination of silicone oil microparticles (Kahook et al., 2010; Liu et al., 2011).

In a document made available at ANVISA website, Roche discourages physicians from fractioning the product Avastin $^{\circledR}$, which contains the drug bevacizumab, due to the adverse events reported during marketing of this drug and identified in the pharmacovigilance monitoring. Furthermore, the manufacturer declares that the vial does not contain preservatives, thus, the product contamination is associated with fractioning.

As per the bevacizumab package insert, the medication does not contain any antimicrobial preservative; therefore, after opened, caution should be taken to ensure the sterility of the prepared solution. After mixing with saline solution for administration, the product should be used immediately and should only be stored in a refrigerator $\left(2-8^{\circ} \mathrm{C}\right)$ for 24 hours.

Similarly, the Veteran Affairs, one of the United States departments that manages a wide chain of hospitals in the United States, has issued a report prohibiting the fractioned use of bevacizumab after reports of cases of serious eye events. The use of Avastin is currently 
approved, but it is restricted to one ampoule per syringe, i.e., drug fractioning is not possible.

\section{Clinical Protocol and Therapeutic Guidelines for AMD - Public Consultation No. 10, dated September 2012}

On September 12, 2012, the Secretaria de Atenção à Saúde [Health Care Department] of the Ministry of Health released the Clinical Protocol and Therapeutic Guidelines - Age-Related Macular Degeneration (neovascular form) for public consultation (PUBLIC CONSULTATION No. 10, DATED SEPTEMBER 12, 2012).

The protocol aims at establishing parameters about AMD in Brazil and national guidelines for diagnosis, treatment and follow-up of the subjects with this disease.

These guidelines incorporate ranibizumab as a therapeutic option; however, they consider the use of bevacizumab (off-label indication). Although the protocol claims that specialized literature shows low level results of therapeutic evidence, the inclusion of bevacizumab is justified as a safe alternative with a higher costeffectiveness when compared to ranibizumab.

\section{CONCLUSION}

This review work allowed the conclusion that the off-label indication of bevacizumab shows increased risks for patients when compared to the product with a specific therapeutic indication for AMD treatment, ranibizumab. These risks specially refer to the significant increase in adverse events. Furthermore, the risks related to multi-dose vials use for the patients were evidenced. These additional risks regard microbial contamination due to the multiple uses and reduced dose precision of the product. Therefore, the proposal of the Clinical Protocol and Therapeutic Guidelines for AMD treatment, as shown in Public Consultation No.10, dated September 12, 2012, may cause unnecessary risks for patients.

\section{REFERENCES}

ARTUNAY, O.; YUZBASIOGLU, E.; RASIER, R.; SENGÜL, A.; BAHCECIOGLU, H. Incidence and management of acute endophthalmitis after intravitreal bevacizumab (Avastin) injection. Eye, v.23, p.2187-2193, 2009.

AVASTIN Bevacizunabe. Responsável técnico Guilherme N. Ferreira. Rio de Janeiro: Roche, 2011. [Bula de Remédio].
AVIS, K.E.; LEVCHUK, J.W. Parenteral preparations. In: REMINGTON: the science and practice of pharmacy. 20.ed. Baltimore: Lippincott Williams \& Wilkins, 2000. p. $780-806$.

FARMACOPEIA Brasileira. 5.ed. São Paulo: Atheneu, 2010.

BRASIL. Intrução Normativa n.14, de 27 de outubro de 2009. Aprova os guias de farmacovigilância para a execução da RDC n.4, de 10.02.2009. Available at: <http://portal. anvisa.gov.br/wps/wcm/connect/13e6a0804ad31c9aa21 cafa337abae9d/Instrucao_Normativa_n_14_de_27_de outubro_de_2009.pdf?MOD=AJPERES $>$. Accessed on: 28 Nov. 2012.

BRASIL. Consulta Pública n.10, de 12 de setembro de 2012. Protocolo clínico e diretrizes terapêuticas da degeneração macular relacionada com a idade (forma neovascular). Available at: <http://portal.saude.gov.br/portal/arquivos/ pdf/cp_sas_10_dmri_2012.pdf $>$. Accessed on: 28 Nov. 2012.

BRASIL. Resolução RDC n.96, de 17 de dezembro de 2008. Dispõe sobre a propaganda, publicidade, informação e outras práticas cujo objetivo seja a divulgação ou promoção comercial de medicamentos. Available at: $<\mathrm{http}: / / \mathrm{www}$. anvisa.gov.br/propaganda/rdc/rdc_96_2008_consolidada. pdf>. Accessed on: 28 Nov. 2012.

BRASIL. Farmacovigilância da Anvisa lança o seu primeiro boletim. Bol. Farmacovigilância, v.1, n.1, p.1-5, 2012. Available at: $<$ http://portal.anvisa.gov.br/wps/wcm/connect/ fac881804bed0acd9451ddbc0f9d5b29/Farmaco +1 . pdf?MOD=AJPERES $>$. Accessed on: 28 Nov. 2012.

BRASIL. Ministério da Saúde. Agência Nacional de Vigilância Sanitária. Registro de medicamentos: como a Anvisa vê o uso off label de medicamentos. Brasília, 2005 Available at <http://www.anvisa.gov.br/medicamentos/registro/ registro_offlabel.htm>. Accessed on: 10 Nov. 2012.

BROWN, D.M.; KAISER, P.K.; MICHELS, M.; SOUBRANE, G.; HEIER, J.S.; KIM, R.Y.; SY, J.P.; SCHNEIDER, S.; ANCHOR STUDY GROUP. Ranibizumab versus verteporfin for neovascular age-related macular degeneration. N. Engl. J. Med., v.355, p.1432-1444, 2006.

CAMPOCHIARO, P.A. Ocular neovascularisation and excessive vascular permeability. Expert. Opin. Biol. Ther. v.4, p.1395-1402, 2004. 
CHAKRAVARTHY, U.; HARDING, S.P.; ROGERS, C.A. Ranibizumab versus Bevacizumab to treat neovascular age-related macular degeneration: one-year Findings from the IVAN randomized trial. Ophthalmology, v.119, p.1399$1411,2012$.

DADE, J.; WILCOX, M.; KAY, L. Hazards of multiple use of pharmaceutical solutions. Lancet, v.356, p.1684-1685, 2000 .

DI PAOLO, E.R.; STOETTER, H.; COTTING, J.; FREY, P.; GEHRI, M.; BECK-POPOVIC, M. Unlicensed and off label drug use in a Swiss paediatric university hospital. Swiss Med. Wkly., v.136, p.218-222, 2006.

ELLIS, L.M. Mechanisms of action of bevacizumab as a component of therapy for metastatic colorectal cancer. Semin. Oncol., v.33, suppl.10, p.S1-S7, 2006.

GARFINKLE, B.D., HENLEY, M.W. Sterilization. In: REMINGTON: the science and practice of pharmacy. 20.ed. Baltimore: Lippincott Williams \& Wilkins, 2000. p.753-779.

GOLDBERG, R.A.; FLYNN Jr, H.W.; ISOM, R.F.; MILLER, D.; GONZALES, S. An outbreak of streptococcus endophthalmitis after intravitreal injection of bevacizumab. Am. J. Ophthalmol., v.153, p.204-208, 2012.

GRAGOUDAS, E.S.; ADAMIS, A.P.; CUNNINGHAM, E.T. JR; FEINSOD, M.; GUYER, D.R. Pegaptanib for neovascular age-related macular degeneration. N. Engl. J. Med., v.351, p.2805-2816, 2004.

GRUNWALD, J.E.; DANIEL, E.; YING, G.S.; PISTILLI, M.; MAGUIRE, M.G.; ALEXANDER, J.; WHITTOCKMARTIN, R.; PARKER, C.R.; SEPIELLI, K.; BLODI, B.A.; MARTIN, D.F. Photographic assessment of baseline fundus morphologic features in the comparison of age-related macular degeneration treatments trials. Ophthalmology, v.119, p.1634-1641, 2012.

HENRY, B.; PLANTE-JENKINS, C.; OSTROWSKA, K. An outbreak of Serratia marcescens associated with the anesthetic agent propofol. Am. J. Infect. Control., v.29, p.312-315, 2001.

KAHOOK, M.Y.; LIU, L.; RUZYCKI, P.; MANDAVA, N.; CARPENTER, J.F.; PETRASH, J.M.; AMMAR, D.A. High-molecular-weight aggregates in repackaged bevacizumab. Retina, v.30, n.6, p.887-892, 2010.
KIRSCHKE, D.L.; JONES, T.F.; STRATTON, C.W.; BARNETT, J.A.; SCHAFFNER, W. Outbreak of joint and soft-tissue infections associated with injections from a multiple-dose medication vial. Clin. Infect. Dis., v.36, p.1369-1673, 2003.

LIU, L.; AMMAR, D.A.; ROSS, L.A.; MANDAVA, N.; KAHOOK, M.Y.; CARPENTER, J.F. Silicone oil microdroplets and protein aggregates in repackaged bevacizumab and ranibizumab: effects of long-term storage and product mishandling. Invest. Ophthalmol. Visual Sci., v.52, p.1023-1034, 2011.

LUCENTIS Ranibizumabe. Responsável técnico Virginia da Silva Giraldi. São Paulo: Novartis, 2011. [Bula de Remédio].

MAINI, R.; CLAIR, W.; BREEDVELD, F.; FURST, D.; KALDEN, J.; WEISMAN, M.; SMOLEN, J.; EMERY, P.; HARRIMAN, G.; FELDMANN, M. Infliximab (chimeric anti-tumour necrosis factor $\alpha$ monoclonal antibody) versus placebo in rheumatoid arthritis patients receiving concomitant methotrexate: a randomised phase III trial. Lancet, v.354, n.9194, p.1932-1939, 1999.

MATTNER, F.; GASTMEIER, P. Bacterial contamination of multiple-dose vials: a prevalence study. Am. J. Infect. Control, v.32, p.12-16, 2004.

MARTIN, D.F.; MAGUIRE, M.G.; FINE, S.L.; YING, G.S.; JAFFE, G.J.; GRUNWALD, J.E.; TOTH, C.; REDFORD, M.; FERRIS III, F.L. Ranibizumab and bevacizumab for treatment of neovascular age-related macular degeneration: two-year results. Ophthalmology, v.119, p.1388-1398, 2012.

MARTIN, D.F.; MAGUIRE, M.G.; FINE, S.L. Bevacizumab: not as good with more adverse reactions? Response. Clin. Experiment. Ophthalmol., v.39, p.718-720, 2011.

MELNYK, P.S.; SHEVCHUK, Y.M.; CONLY, J.M.; RICHARDSON, C.J. Contamination study of multipledose vials. Ann. Pharmacother., v.27, p.274-278, 1993.

MILLER, K.; WANG, M.; GRALOW, J.; DICKLER, M.; COBLEIGH, M.; PEREZ, A.E.; SHENKIER, T.; CELLA, D.; DAVIDSON, N.D. Paclitaxel plus bevacizumab versus paclitaxel alone for metastatic breast cancer. N. Engl. J. Med., v.357, p.2666-2676, 2007. 
MORO, M.L.; MAFFEI, C.; MANSO, E.; MORACE, G.; POLONELLI, L.; BIAVASCO, F. Nosocomial outbreak of systemic candidosis associated with parenteral nutrition. Infect. Control Hosp. Epidemiol., v.11, p.27-35, 1990.

MOSHFEGHI, D.M.; KAISER, P.K.; SCOTT, I.U.; SEARS, J.E.; BENZ, M.; SINESTERRA, J.P.; KAISER, R.S; BAKRI, S.J.; MATURI, R.K.; BELMONT, J.; BEER, P.M.; MURRAY, T.G.; QUIROZ-MERCADO, H.; MIELER, W.F. Acute endophthalmitis following intravitreal triamcinolone acetonide injection. Am. J. Ophtalmol., v.136, p.791-796, 2003.

NAKASHIMA, A.K.; HIGHSMITH, A.K.; MARTONE, W.J. Survival of Serratia marcescens in benzalkonium chloride and in multiple-dose medication vials: relationship to epidemic septic arthritis. J. Clin. Microbiol., v.25, p.1019$1021,1987$.

NAUBERT, A.; DORMANN, H.; WEISS, J.; EGGER, T.; CRIEGEE-RIECK, M.; RASCHER, W.; BRUNE, K.; HINZ, B. The impact of unlicensed and off-label drug use on adverse drug reactions in paediatric patients. Drug Saf., v.27, p.1059-1067, 2004.

P A T E L, H .; B E L L, D .; M O L O K H I A, M .; SRISHANMUGANATHAN, J.; PATEL, M.; CAR, J.; MAJEED, A. Trends in hospital admissions for adverse drug reactions in England: analysis of national hospital episode statistics 1998-2005. BMC Clin. Pharmacol., v.7, p.1-11, 2007.

RADLEY, D.C.; FINKELSTEIN, S.N.; STAFFORD, R.S. Off-label prescribing among office-based physicians. Arch. Intern. Med., v.166, p.1021-1026, 2006.

RANPURA, V.; PULIPATI, B.; CHU, D.; ZHU, X.; WU, S. Increased risk of high-grade hypertension with bevacizumab in cancer patients: a meta-analysis. Am. J. Hypertens., v.23, p.460-468, 2010.

REGATIERI, C.; RODRIGUES, E.; MELO, G.; MAIA, M.; FARAH, M.E. Anticorpos monoclonais em oftalmologia: realidades e perspectivas para retina e vítreo. Retina \& Vitreo, v. 21, p. 5-10, 2010.

REMINGTON: the science and practice of pharmacy. 20.ed. Baltimore: Lippincott Williams \& Wilkins, 2000. 2077 p.
RICH, R.M.; ROSENFELD, P.J.; PULIAFITO, C.A.; DUBOVY, S.R.; DAVIS, J.L.; FLYNN, H.W. JR.. Short-term safety and efficacy of intravitreal bevacizumab (Avastin) for neovascular age-related macular degeneration. Retina, v.26, p.495-511, 2006.

ROSENFELD, P.J.; BROWN, D.M.; HEIER, J.S.; BOYER, D.S.; KAISER, P.K.; CHUNG, C.Y.; KIM, R.Y. Ranibzumab for neovascular age-related macular degeneration. N. Engl. J. Med., v.355, n.14, p.1419-1431, 2006.

ROSENFELD, P.J.; MOSHFEGHI, A.A.; PULIAFITO, C.A. Optical coherence tomography findings after an intravitreal injection of bevacizumab (avastin) for neovascular agerelated macular degeneration. Ophthalmic Surg. Lasers Imaging, v.36, p.331-335, 2005.

SANDLER, A.; GRAY, R.; PERRY, M.C.; BRAHMER, J.; SCHILLER, J.H.; DOWLATI, A.; LILENBAUM, R.; JOHNSON, D.H. Paclitaxel-carboplatin alone or with bevacizumab for non-small-cell lung cancer. N. Engl. J. Med., v.355, p.2542-2550, 2006.

SANTOS, R.V.; LIMA, P.M.G.; NITSCHE, A.; HARTH, F.M.; MELO, F.Y.; HELCIO, T.; AKAMATSU, H.T.; LIMA, H. Aplicações terapêuticas dos anticorpos monoclonais. Rev. Bras. Alergia Imunopatol., v.29, p.77-85, 2006.

SCARTOZZI, M.; GALIZIA, E.; CHIORRINI, S.; GIAMPIERI, R.; BERARDI, R.; PIERANTONI, C.; CASCINU, S. Arterial hypertension correlates with clinical outcome in colorectal cancer patients treated with first-line bevacizumab. Ann. Oncol., v.20, p.227-230, 2009.

THOMAS, K.; SCHMIDT, M.S. Glaxo agrees to pay \$3 billion in fraud settlement. New York Times. July 2, 2012 , Business Day, 2p. Available at: <http://www.nytimes. com/2012/07/03/business/glaxosmithkline-agrees-to-pay3-billion-in-fraud-settlement.html?_r=0>. Assessed on: 15 nov. 2012.

UNITED STATES. Department of Justice. Office of Public Affairs. U.S. Pharmaceutical Company Merck Sharp \& Dohme Sentenced in Connection with Unlawful Promotion of Vioxx: judge imposes nearly \$322 million fine for illegal marketing. Thursday, April 19, 2012. Available at: <http:// www.justice.gov/opa/pr/2012/April/12-civ-497.html>.15 nov. 2012. 
UNITED STATES. Department of Justice. Office of Public Affairs. Abbott Labs to Pay $\$ 1.5$ Billion to Resolve Criminal and Civil Investigations of Off-Label Promotion of Depakote, 2012. Available at: http://www.justice.gov/opa/ pr/2012/May/12-civ-585.html. Accessed on: 28 Nov. 2012.

UNITED STATE. Department VA Gives Ocular Avastin Another Shot. U.S. reinstated use of intraocular Avastin on October 18. of Veterans Affairs. Available at: <http://www.revoptom. com/content/d/news_review/c/31580/>. Accessed on: 10 Nov. 2012.

UNITED States Pharmacopeia: USP35; The National Formulary NF30. Rockville: United States Pharmacopeial Convention, 2012.
WEINBLATT, M.E.; KEYSTONE, E.C.; FURST, D.E.; MORELAND, L.W.; WEISMAN, M.H.; BIRBARA, C.A.; TEOH, L.A.; FISCHKOFF, S.A; CHARTASH, E.K. Adalimumab, a fully human anti-tumor necrosis factor $\alpha$ monoclonal antibody, for the treatment of rheumatoid arthritis in patients taking concomitant methotrexate: The ARMADA trial. Arthritis Rheum., v.48, p.35-45, 2003.

WIENS, A.; VENSON, R.; CORRER, C.J.; OTUKI, M.F.; PONTAROLO, R. Meta-analysis of the efficacy and safety of adalimumab, etanercept, and infliximab for the treatment of rheumatoid arthritis. Pharmacotherapy, v.30, p.339-353, 2010 .

Received for publication on $15^{\text {th }}$ January 2013 Accepted for publication on $06^{\text {th }}$ September 2013 